\title{
Experimental simulation of proppant permeability in hydraulic fracturing at extended time under bottom-hole conditions
}

\author{
Ali Seyfeddine Guenaoui ${ }^{1}\left[\right.$ Abdelmadjid Dobbi $^{1} \cdot$ Hamid Lebtahi ${ }^{1} \cdot$ Ahmed Ali Zerrouki $^{1}$
}

Received: 30 July 2021 / Accepted: 26 October 2021 / Published online: 9 November 2021

(c) The Author(s) 2021

\begin{abstract}
During hydraulic fracturing treatment, huge quantities of gel are pumped into the formation to initiate the fracture, maintain it open and transport the proppant. The fracture dimensionless conductivity (Fcd) is a key parameter to optimize the fracturing design, to estimate the productivity Index (PI) and the folds of increase (FOI). However, these parameters are affected by the gel residues which decrease the fracture conductivity; thus, the proppant cleanup is a very important step to avoid additional damage caused by fracturing fluid due to high gel concentration and the extended time of gel staying in the fracture before cleanup. Throughout the life of Hassi Messaoud, Algeria field, hydraulic fracturing technique has been aggressively used mainly in four producing formations in the Cambrian, with hard formation characteristics, an average permeability range and low reservoir pressure (0.15-0.45 psi/ft) and high stress value between 6000 and $9000 \mathrm{psi}$. In this paper, an experimental simulation is applied using a self-made cell to determine the effect of different parameters on the fracture conductivity under various bottom-hole conditions where different variables were used: effect of Proppant type, guar gel concentration, temperature, breaker concentration and closure pressure at extended time. An important drop in fracture conductivity was observed varied between 10 and $80 \%$ under stresses at interval of $2000 \mathrm{psi}$ and $8000 \mathrm{psi}$, gel concentration up to $200 \mathrm{lb} / 1000$ gal at extended time and temperature.
\end{abstract}

Keywords Hydraulic fracturing · Proppant · Permeability · Fracturing fluid · Experimental simulation

$\begin{array}{ll}\text { Abbreviations } \\ \text { Fcd } & \text { Fracture conductivity dimensionless } \\ \text { PI } & \text { Productivity index } \\ \text { FOI } & \text { Folds of increase } \\ \text { HSP } & \text { High strength proppant }\end{array}$

\section{Introduction}

The primary objective of a hydraulic fracturing treatment is to increase the well productivity by creating a highly conductive path compared to the reservoir permeability. Fracture conductivity has been under investigation since the inception of hydraulic fracturing.

Ali Seyfeddine Guenaoui

guenaouialiseyfeddine@gmail.com

1 Laboratory of Underground Oil, Gas and Aquifer Reservoirs, Faculty of Hydrocarbons, Renewable Energies, Earth and Universe Sciences, Kasdi Merbah University of Ouargla, 30000 Ouargla, Algeria
In 1975, Cooke introduced Effect of Fracturing Fluids on Fracture Conductivity, Kozeny model was used by Cooke to measure the residue amount in the proppant pack compared to the permeability predicted. But the temperature and longterm conductivity were not investigated (Cooke 1975). In 1985, the effect of fracturing fluid on proppant conductivity was studied by Kim (1985) using an API cell. Permeability impairment of $30 \%$ to $50 \%$ was reported for polymer concentrations between 40 and 100 lb/1000 gal. However, the damage associated with the gel at extended time in the proppant pack was not considered. Roodhart (1986), Penny (1987) and McDaniel (1988) introduced a complex experiment to simulate field conditions by allowing fluid leak-off through the core during pumping and closure. However, they did not investigate the effect of all parameters at extended time, and the experiment was very complicated. In 1987, a drop of $85 \%$ was observed after introducing Ohio sandstones to replace the steel pistons, temperature was increased to $65{ }^{\circ} \mathrm{C}$ or $120{ }^{\circ} \mathrm{C}$, and the closure pressure was applied for $50 \mathrm{~h}$ (Palisch 2007). However, the fracturing fluid damage was not taken in consideration. In 1989, the proppant pack conductivity standard procedures were developed by the 
American Petroleum Institute (API) using Cooke conductivity cell and were documented under (API RP 61 1989). Generally, $2 \mathrm{lb} / \mathrm{ft} 2$ of proppant concentration between two steel pistons maintaining closure pressure for $15 \mathrm{~min}$, pumping $2 \% \mathrm{KCl}$ at $2 \mathrm{~mL} / \mathrm{min}$ to measure the proppant conductivity. Nonetheless the procedures did not include the damage associated with the fracturing fluid at extended time. Samuelson and Constein (1996), presented laboratory data of degraded fracturing fluids at temperatures above $80^{\circ} \mathrm{C}$ using laboratory fracture conductivity results and residual polymer analysis. The experiments did not include the study of the parameters mentioned at extended time more than one day.

In 2000, proppant conductivity was investigated by Mathew Samuel et al. (2000) using Viscoelastic surfactant fluid, Field results have shown that $\sim 85 \%$ and $100 \%$ retained conductivity for the proppant pack was recorded. However, this type of fluids is very expansive and not usually used in Algeria. In 2006 (International Standard 2006) was published replacing the API RP 16 for long-term conductivity testing, the procedures consist of applying the closure stress for $50 \mathrm{~h} \pm 2 \mathrm{~h}$, when the $2 \%$ $\mathrm{KCl}$ fluid is forced into the cell the flow rate, proppant width and temperature are measured (Kaufman 2007). But the procedures did not include the effect of fracturing fluid on proppant conductivity. In 2015, a new method of proppant pack permeability assessment was proposed by Lutynski (2014) where proppant is placed into a rock sample with induced fracture. The rock sample was a Tumlin sandstone. Different confining pressure were applied (3-16 MPa). However, this study focused on the damage caused by the stress. In 2018, (Abhinav Mittal 2018) et al. used a conductivity cell made to measure the fracture permeability applying an axial load of 5000 psi using Brine at $120{ }^{\circ} \mathrm{C}$, over extended time (10-60 days). However, the effect of polymer was not investigated. In 2019, (Sterling
Richard 2019) et al. improved the proppant conductivity measuring method published by API by adding the vibration for more repeatable grain packing structure and compact structure. But all other procedures were kept the same with no fluid damage.

While significant progress has been made in the effort to realistically evaluate and quantify proppant pack permeability due to gel damage, very little has been disclosed to study the effect of stress, fracturing fluid and temperature at extended time before cleanup on proppant conductivity.

By January 2019, almost 500 wells have been hydraulically fractured in Hassi Messaoud, fracturing treatments performed in this field differ significantly from others. To maintain the current production levels, stimulation treatments are continually performed to improve the reservoir recovery (Soto Maldonado and Aoun 2019), however conventional stimulation technologies such as matrix acidizing and water-based propped fracturing treatments with polymer fluid system often have insufficient results (Table 1, well 1 and 7). This circumstance can be explained by unachieved planed fracture geometry parameters and low retained fracture conductivity due to gel damage from high polymer loading and the time taken between the closure and cleanup operation (Table 1, well 6 and 7), this delay is mainly because of the unavailability of Coiled Tubing units due to high well interventions activity and because of the extra cost of working at night shifts.

In Hassi Messaoud field, this phenomenon is very commonly observed, below resumed in Table 1 are 10 wells fractured in Hassi Messaoud, the period between the fracturing treatment and the cleanup operation, the production rate before and after the treatment are regrouped as well.

Relatively high viscosity fluids are used to transport proppant into the fracture. Leaving a high viscosity fluid in the fracture would reduce the permeability of the proppant pack

Table 1 Data of 10 wells fractured in Hassi Messaoud between 2018 and 2020

\begin{tabular}{|c|c|c|c|c|c|c|}
\hline Well & $\begin{array}{l}\text { Fracturing treat- } \\
\text { ment Date }\end{array}$ & $\begin{array}{l}\text { Gel concentration } \\
\text { (lb/1000 gal) }\end{array}$ & Clean up date & $\begin{array}{l}\text { Period between fracturing } \\
\text { and cleanup (Day) }\end{array}$ & $\begin{array}{l}\text { Pre-frac production } \\
\text { rate }\left(\mathrm{m}^{3} / \mathrm{h}\right)\end{array}$ & $\begin{array}{l}\text { Post-frac } \\
\text { production rate } \\
\left(\mathrm{m}^{3} / \mathrm{h}\right)\end{array}$ \\
\hline Well 1 & 21-Mar-20 & 35 & 22-Mar-20 & 1 & Closed & 0.00 \\
\hline Well 2 & 30-Mar-20 & 35 & 31-Mar-20 & 1 & Closed & 0.50 \\
\hline Well 3 & 2-Apr-20 & 35 & 2-Apr-20 & 0 & Closed & 2.48 \\
\hline Well 4 & 30-Jun-20 & 35 & 1-Jul-20 & 1 & Closed & 0.63 \\
\hline Well 5 & 11-Jul-20 & 35 & 12-Jul-20 & 1 & Closed & 2.45 \\
\hline Well 6 & 11-Jan-19 & 35 & 13-Jan-19 & 2 & Closed & 2.15 \\
\hline Well 7 & 15-Jan-19 & 35 & 18-Jan-19 & 3 & Closed & 1.86 \\
\hline Well 8 & 5-Feb-19 & 35 & 7-Feb-19 & 2 & Closed & 2.00 \\
\hline Well 9 & 7-Sep-19 & 35 & 8-Sep-19 & 1 & 0.60 & 1.74 \\
\hline Well 10 & 8-Aug-18 & 35 & 9-Aug-18 & 1 & Closed & 0.00 \\
\hline
\end{tabular}

Some wells were closed before hydraulic treatments due to non-rentability 

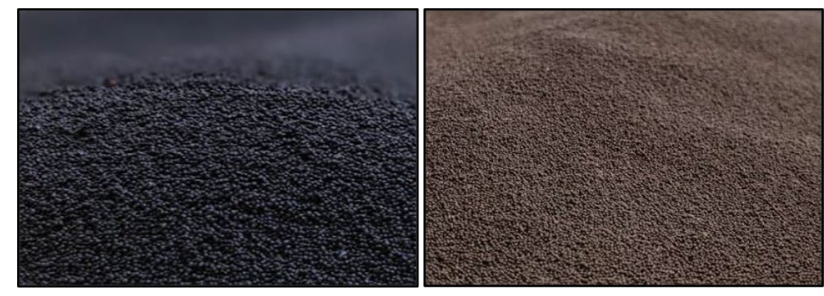

Fig. 1 20/40 and 30/50 HSP Proppant used

Table 2 Mesh size, sphericity and roundness results of proppants used

\begin{tabular}{lllll}
\hline Proppant & Sphericity & Roundness & Mesh size \% & $\begin{array}{l}\text { Specific } \\
\text { gravity }\end{array}$ \\
\hline Bauxite 20/40 & 0.5 & 0.3 & $20 / 40=96 \%$ & 3.6 \\
Bauxite 30/50 & 0.5 & 0.4 & $30 / 50=93 \%$ & 3.5 \\
\hline
\end{tabular}

to oil and gas, limiting the effectiveness of the fracturing treatment (Penny 1987; Brannon 1992).

The objective of these study is to determine the effect of the fracturing fluid concentration at extended time under fracture stress and formation temperature and what will be the effect of time on fracture permeability under the mentioned conditions.

This paper, therefore, will conduct series of experiments simulation to identify the effect of the mentioned parameters on fracture conductivity under bottom-hole conditions using a self-made cell which is simple, robust and original.

\section{Materials}

\section{Proppant}

To simulate the effect of pressure, fracturing fluid and temperature two types of proppant were selected: 20/40 bauxite and 30/50 bauxite (Fig. 1) which are the most types used in Hassi Messaoud field.

According to ISO 13503-2:2006 standard, the sphericity, roundness, mesh size and specific gravity of proppant represented in Table 2 were tested, a microscope Bresser $5,013,000(300-500 \mu \mathrm{m})$ was used to assess the sphericity and roundness for proppant grains using Krumbein/Sloss diagram (Fig. 2). Due to the high stress profile recorded in Hassi Messaoud zones, high strength proppant type was used in the proppant testing.

\section{Guar}

Because of their low cost, high performance and ease of handling, water-base fluids are the most widely used fracturing

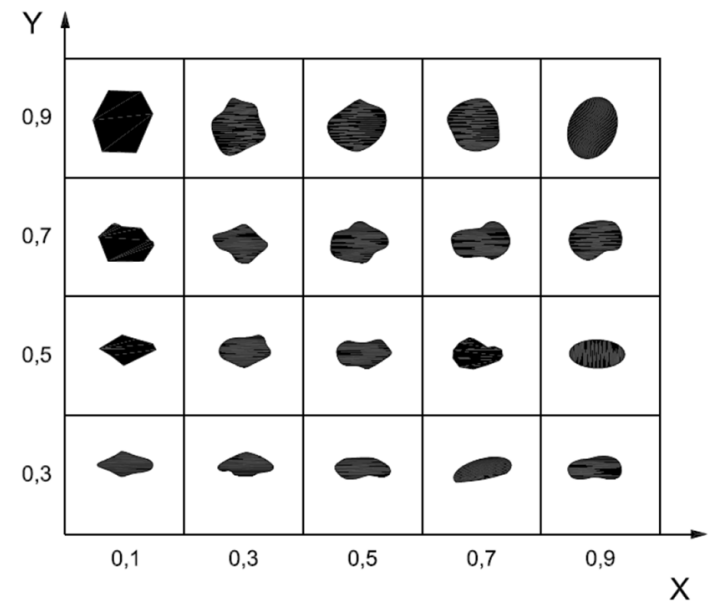

Fig. 2 Krumbein/Sloss diagram for visual assessment of sphericity and roundness (International Standard, I. 1.-5 2006)

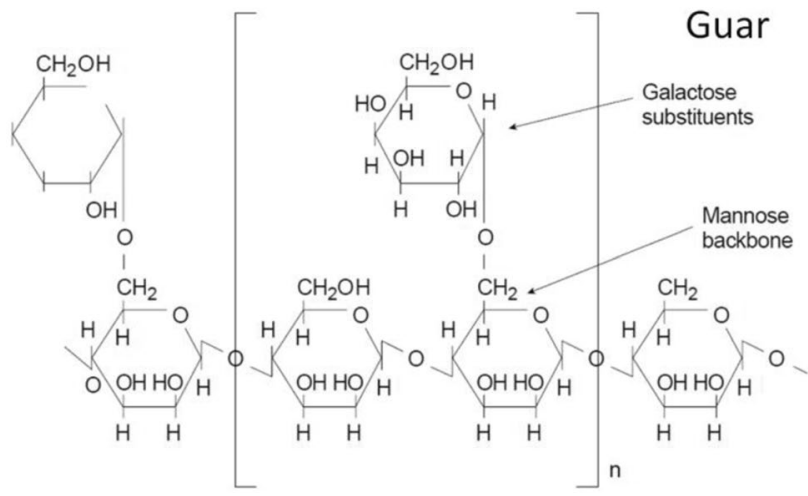

Fig. 3 Guar structure (Economides 2000)

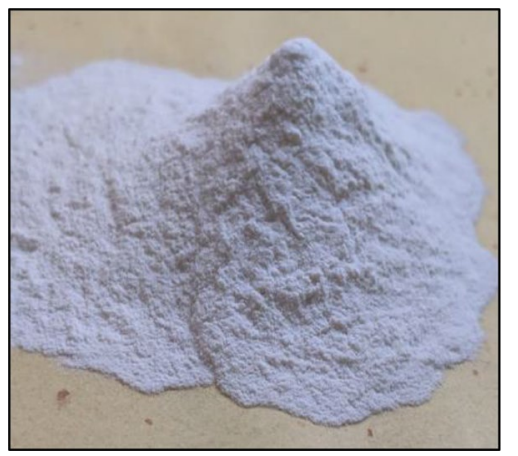

Fig. 4 Guar sample used in tests

fluids (Economides 2000), they are the most type used in Hassi Messaoud at concentration between 25 and $40 \mathrm{lb} / 1000$ gal, thus Guar gel powder was used to prepare the linear gel in this experiment. Guar is a long-chain (Figs. 3, 4), high-molecular-weight polymer composed of mannose and galactose sugars (polysaccharides) (Whistler 1959).

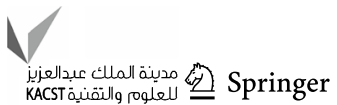


It has been estimated that fluid loss during the treatment and during closure increases the polymer concentration in the fracture after closure thus concentrations used to prepare the linear gel as base fluid was between 50 and $200 \mathrm{lb} / 1000$ gal, because the post-closure polymer concentrations can reach $200 \mathrm{lb} / 1000 \mathrm{gal}$ to $1000 \mathrm{lb} / 1,000$ gal which is 5 to 7 times surface concentration times (Penny 1987) and can reach 20 times (Hawkins 1988) and result in reduced fracture permeability, and therefore fracture conductivity. The fracturing fluid temperature and breakers concentration affects the fracture permeability as well. Crosslinked polymers compounds are difficult to displace, causing significant damage to the proppant pack permeability.

\section{Crosslinker}

Several metal ions can be used to crosslink water-soluble polymers (Conway et al 1980). Borate, Ti (IV), Zr (IV) and $\mathrm{Al}$ (III) compounds are frequently used crosslinkers. The borate compounds (Deuel 1949) react with guar through cis- $\mathrm{OH}$ pairs on the galactose side chains to form a complex, as illustrated in (Fig. 5).

Boric acid represented in Fig. 6 was used as crosslinker as it is one of the most types used in Hassi Messaoud region, a concentration of $10 \mathrm{gal} / 1000 \mathrm{gal}$ was used to prepare the crosslinked fluid for proppant permeability testing.

\section{Breakers}

Gel breakers are used to reduce the viscosity of the fluid intermingled with the proppant. Breakers reduce viscosity by cleaving the polymer into small-molecular-weight fragments. The increased polymer concentration causes a

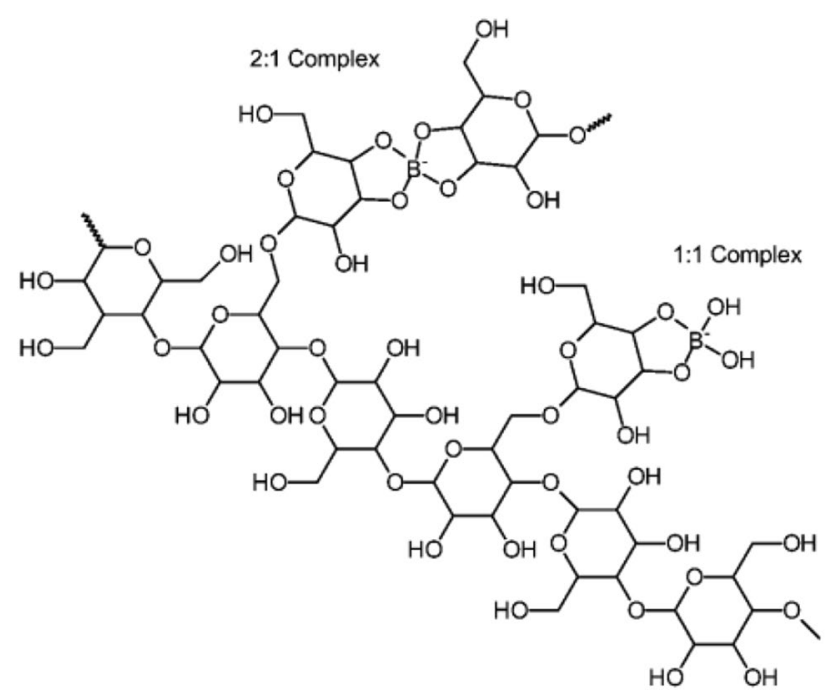

Fig. 5 Borate crosslinked guar (Barati 2011)<smiles>OCC(O)CO</smiles><smiles>OCC(O)CO</smiles><smiles>[Y]C</smiles>

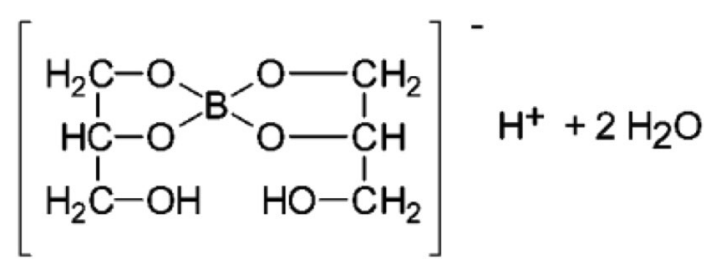

Fig. 6 Proposed crosslinking mechanism (Menjivar 1984)

major increase in viscosity. For example, the viscosity of an unbroken guar fluid containing polymer at $200 \mathrm{lb} / 1000$ gal (20 lb/1000 gal) gel concentrated 10 times because of fluid loss (Pope, 1994). The viscosity of the gel and the molecular weight of the polymer should be significantly reduced to allow rapid cleanup of the sand pack (Almond 1984; Gall 1985).

Inorganic and organic peroxides have been described in the literature (Bielewicz 1998). These materials degrade the polymer chains by oxidative mechanisms, and they are usually used as breakers in Hassi Messaoud area, thus sodium bromate (Fig. 7) were used in the experiments for proppant permeability measurement.

\section{Distilled water and gasoil}

Deionized water was used to prepare the linear gel, and Gasoil was injected into the cell for proppant permeability measurement.

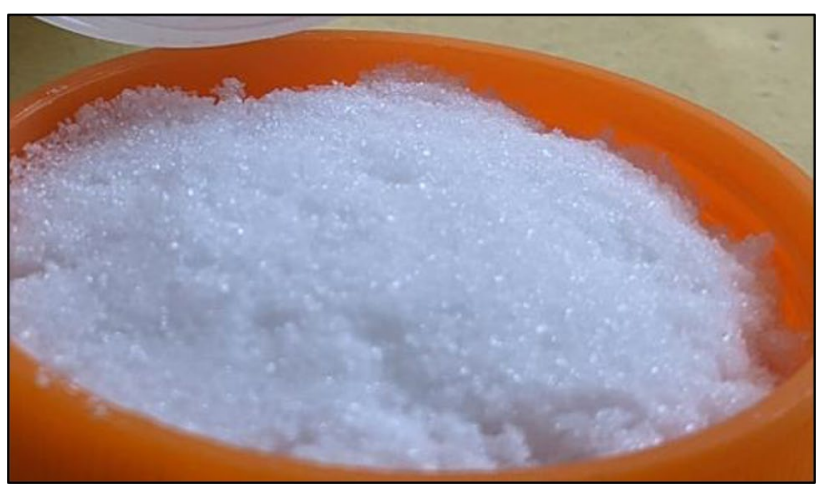

Fig. 7 Sodium bromate breaker 


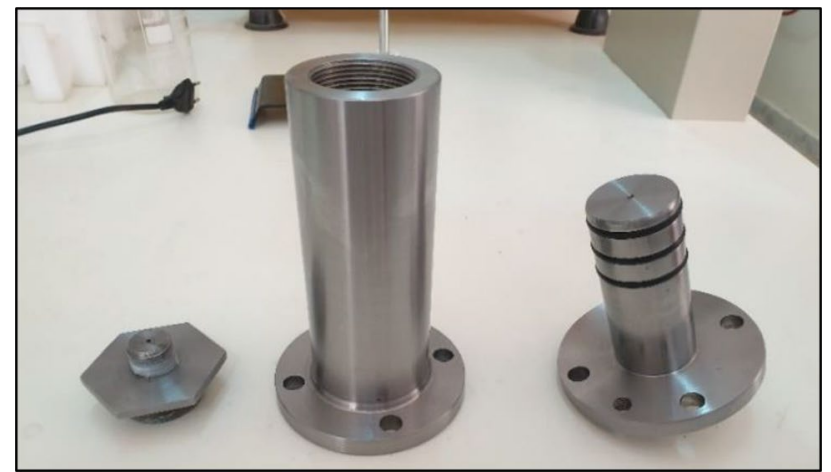

Fig. 8 Self-made Piston components

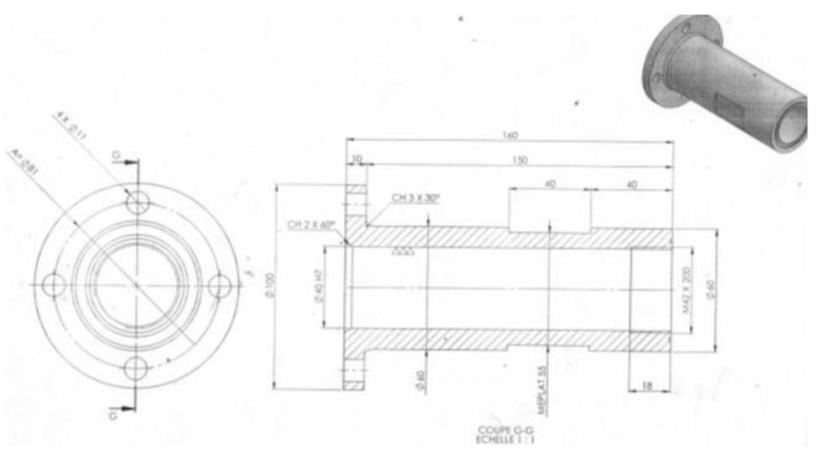

Fig. 9 Cylinder of Self-made Piston for proppant permeability measurement

Sonatrach Gasoil was used to simulate the oil which circulates inside the fracture and which is the responsible for cleanout process. Sonatrach Gasoil viscosity is $0.30 \mathrm{cP}$.

\section{Methodology}

\section{Self-made confinement cell}

In order to measure the permeability of the core sample filled with proppant a self-made permeability confinement cell was proposed (Fig. 8). Inox steel piston was constructed to be filled with proppant and fracturing fluid and subjected to a calculated stress under a constant temperature using different gel concentrations and at extended time.

The piston has a diameter of $4 \mathrm{~cm}$, a length of $15 \mathrm{~cm}$, inlet and an outlet of $2 \mathrm{~mm}$. More details are represented below in (Figs. 9, 10, 11).

The cell is composed of three parts, the first one is the cylinder which has a thread at its base, the second part is the Piston which is equipped with $\mathrm{O}$ rings to insure the sealing and the third part which is the plug with a thread to close the base part of the cylinder. The piston contains
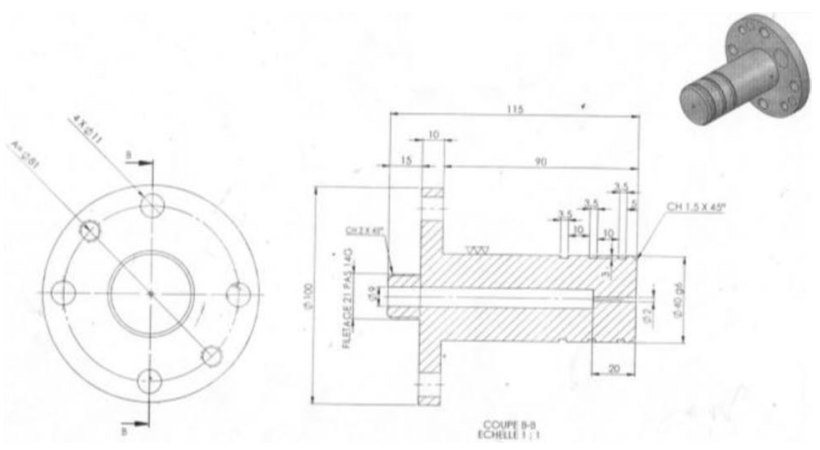

Fig. 10 Piston of Self-made Piston for proppant permeability measurement
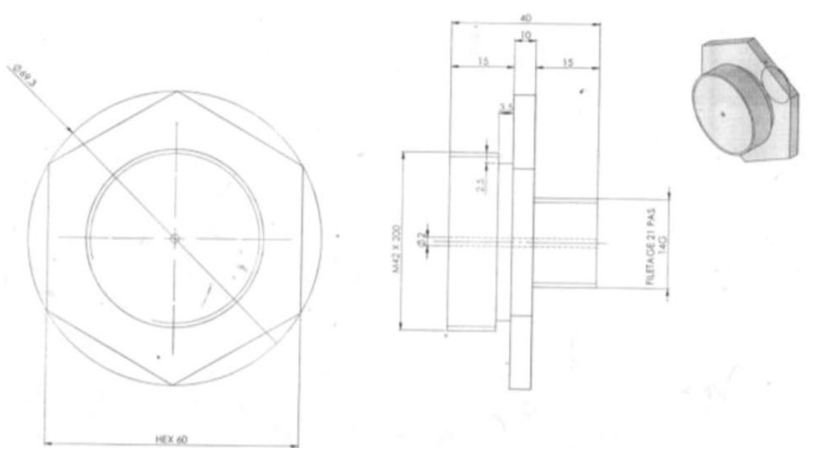

Fig. 11 Plug of Self-made Piston for proppant permeability measurement

also nuts to maintain the pressure applied on proppant inside the cylinder.

\section{Hydraulic press}

To simulate the pressure applied on proppant in the fracture, Big Red hydraulic press (Fig. 12) was used with max force of 10 tons. This press was used to apply the pressure required for proppant permeability measurement. This compact press includes a pressure gauge registering the tonnage being applied.

\section{Universal oven UN30}

Temperature is a very important parameter in hydraulic fracturing and to ensure that the universally applicable lab oven U which is Memmert's classic appliance was used for temperature control in proppant tests. This oven can be monitored by selecting the time and temperature desired for tests. 
Fig. 12 Big Red 10 Ton

Hydraulic Bench Type Press

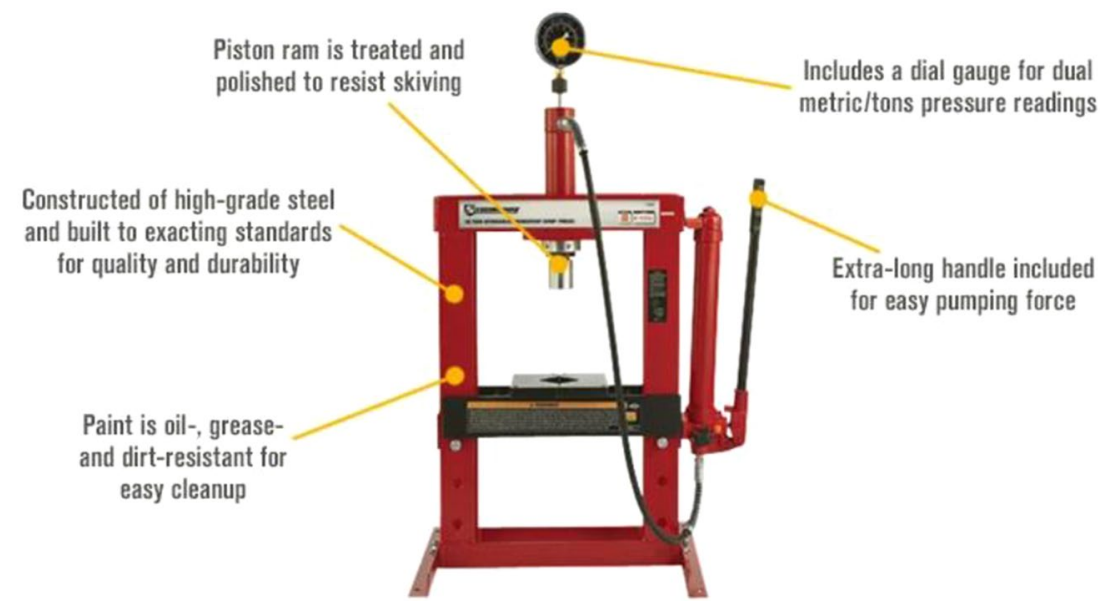

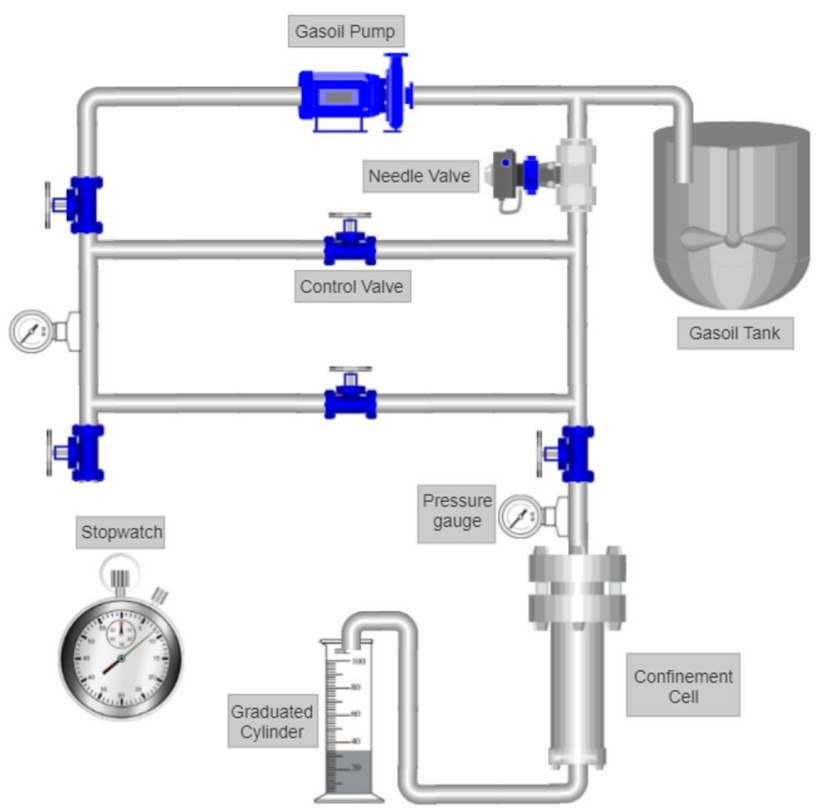

Fig. 14 Installation schematic of the permeability measurement

2. The sodium bromate breaker was added to the linear gel at $20 \mathrm{lb} / 1000 \mathrm{gal}$, which is the concentration usually used in borate crosslinked fracturing fluids used in Hassi Messaoud. The breaker concentration was varied from 0 to $25 \mathrm{lb} / 1000$ gal to check the breaker effect on proppant permeability.

3. The proppant and borate crosslinker were added accordingly the linear gel and mixed.

4. The mixture was then put in the self-made confinement cell and pressurized under different stresses between (2000-8000 psi) using the hydraulic press, the nuts were used to maintain the pressure applied on proppant.

5. The confinement cell was put into the oven at $120^{\circ} \mathrm{C}$ which is the temperature of the Hassi Messaoud Field reservoir and kept at different time between 12 and $72 \mathrm{~h}$. 
Table 3 Test conditions for closure pressure effect on 20/40 and 30/50 HSP proppant permeability

\begin{tabular}{lll}
\hline Pressure (psi) & Temperature $\left({ }^{\circ} \mathrm{C}\right)$ & Time $(\mathrm{h})$ \\
\hline 2000 to 8000 & 120 & 50 \\
\hline
\end{tabular}

Table 4 Test conditions for fracturing fluid effect on 20/40 proppant permeability under $6000 \mathrm{psi}$ and $120^{\circ} \mathrm{C}$

\begin{tabular}{llllll}
\hline \multicolumn{2}{l}{ Gel conc (lb/1000 gal) } & & Time (h) \\
\hline 0 & 50 & 100 & 150 & 200 & 12 \\
\hline 0 & 50 & 100 & 150 & 200 & 24 \\
0 & 50 & 100 & 150 & 200 & 36 \\
0 & 50 & 100 & 150 & 200 & 48 \\
0 & 50 & 100 & 150 & 200 & 72 \\
\hline
\end{tabular}

6. Finally, the confinement cell was retrieved from the oven and connected to the installation. The permeability was calculated by injecting the Gasoil. In the beginning the gel and Gasoil start outflowing from the confinement cell, the gasoil stable rate is maintained until getting clear Gasoil out. The below table represents the parameters used for proppant permeability measurement (Tables 3,4 ).

During proppant permeability measuring, a steady-state flow method was applied. In order to maintain a constant flow, a needle valve was installed behind the confinement cell to maintain the constant pressure. Pressure in the cylinder is monitored by the manometers, therefore the flow rate can be calculated by measuring the volume out of the confinement cell and the time.

The permeability was measured using Darcy law:

$K=\frac{Q \cdot \mu \cdot L}{A \cdot\left(P_{1}-P_{2}\right)}$

$K$ is the proppant pack permeability (Darcy). $\mu$ is the viscosity of test fluid at test temperature (cP). $Q$ is the flow rate $\left(\mathrm{cm}^{3} / \mathrm{s}\right) . L$ is the length between pressure ports $(\mathrm{cm}) . A$ is the cross-sectional area of the test unit perpendicular to flow $\mathrm{cm}^{2} . \Delta P$ is the pressure drop (pressure upstream minus pressure downstream) (atm).

\section{Results and discussion}

\section{Effect of pressure on proppant permeability}

The effect of closure pressure on proppant permeability was investigated using two types of proppant, 20/40 HSP and
30/50 HSP. The confinement cell was filled by the proppant and subjected to a stress values between 2000 and 8000 psi, the proppant was then kept under stress and temperature of $120{ }^{\circ} \mathrm{C}$ for $50 \mathrm{~h}$, and finally, the permeability was measured using Gasoil.

The (Fig. 15) shows the variation of permeability of the proppant as function of stress applied after $50 \mathrm{~h}$. A decrease of proppant permeability for both types 20/40 and 30/50 was observed along with pressure increasing. The highest permeability values were reported at 2000 psi with $380 \mathrm{mD}$ using 20/40 HSP proppant type and $225 \mathrm{mD}$ with $30 / 50$ HSP proppant type. These permeabilities reduced by $89 \%$ under 8000 psi using 30/50 HSP type, in the other side a drop of $66 \%$ was observed using 20/40 HSP type. The rate of permeability impairment was high for both proppant types from 2000 to 6000 psi compared to the interval from 6000 to 8000 psi.

This phenomenon can be explained by fines generated from the proppant grain crushing in critical zones under compaction accompanied with their rearrangement which reduces the space between proppant grains and as result the permeability reduces. More the compaction pressure applied is increased more proppant is crushed, and more fines are generated (Fig. 16). (Krumbein 1943) discussed the effect of grain size on permeability, the below equation was developed for estimating permeability based on grain size:

$k=760 d_{\mathrm{g}}^{2} \exp \left(-1.31 \sigma_{D}\right)$

$k$ is given in Darcies, $d_{\mathbf{g}}$ is the geometric mean grain diameter (in mm). $\sigma_{D}$ is the standard deviation of grain diameter in phi units, where phi $=-\log _{2}(d)$ and $d$ is expressed in millimeters.

In Hassi Messaoud field closure, pressure of fractured reservoir rock variates from 6000 to $9000 \mathrm{psi}$, and thus, the proppant crushing is severe which will affect the retained proppant permeability. Ultra-high strength proppant is recommended in Hassi Messaoud field to gain more retained permeability by reducing the proppant crushing.

\section{Effect of fracturing fluid at extended time on proppant permeability}

The effect of fracturing fluid on proppant permeability was investigated using one type of proppant 20/40 HSP and Guar gel type with borate crosslinker and sodium bromate breaker as mentioned in materials section.

The confinement cell was filled by the proppant and fracturing fluid with different concentrations and subjected to a stress of 6000 psi. The proppant was then kept under stress and temperature of $120^{\circ} \mathrm{C}$ at extended time. The permeability was measured by injecting the Gasoil at room temperature to examine the effect of time between closure and 
Fig. 15 Effect of stress on proppant permeability using 20/40 and 30/50 mesh size HSP proppant

\section{Effect of Stress on Proppant pack permeability}

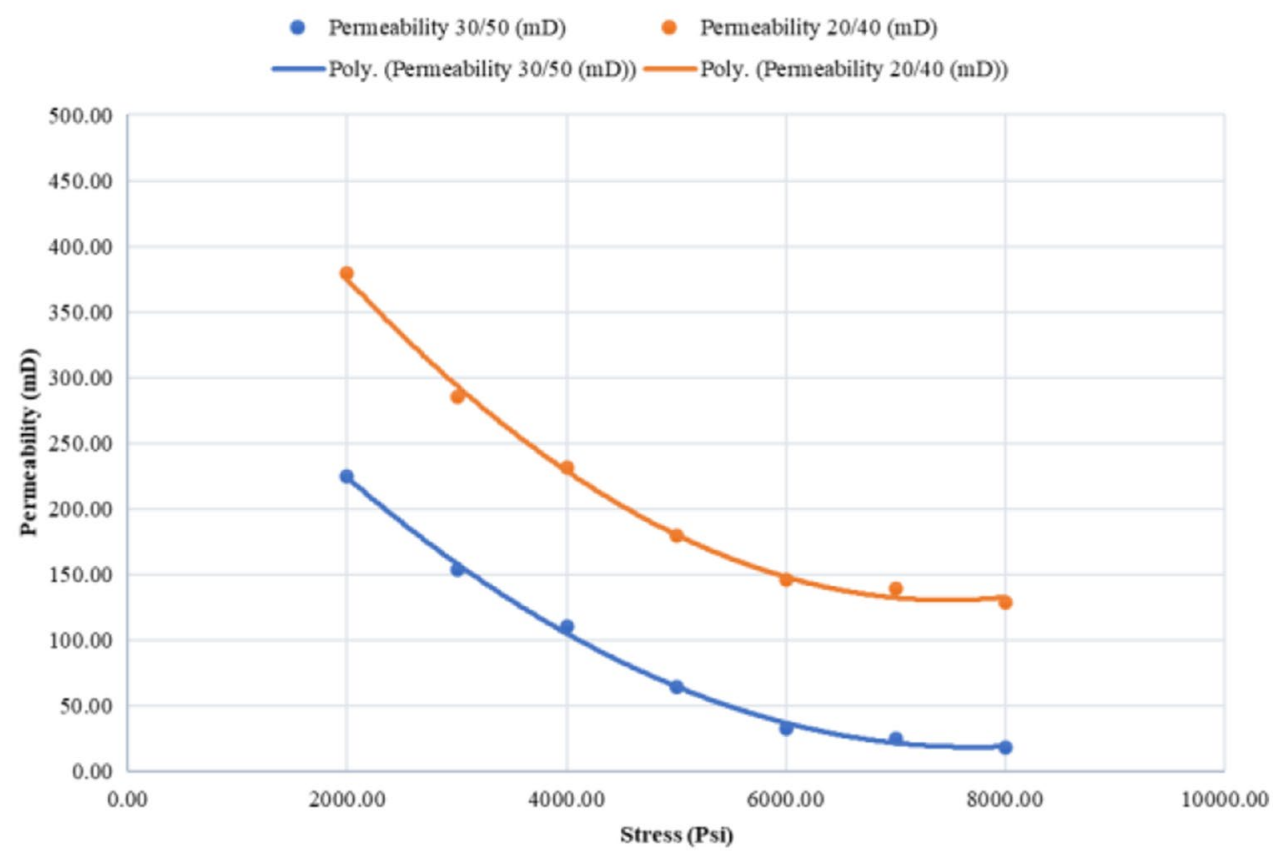

Fig. 16 Effect of grain size on proppant permeability

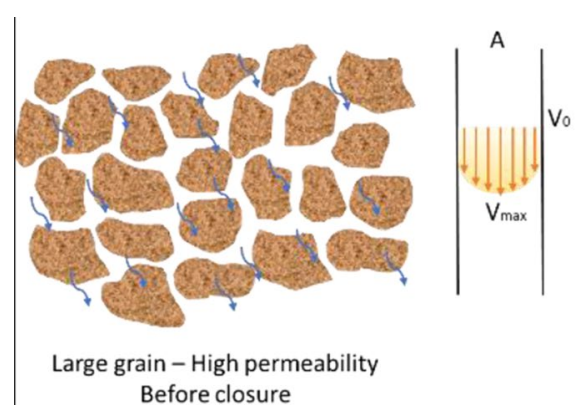

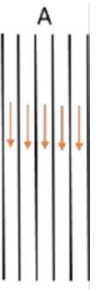

Small grain - Low permeability After closure cleanup operations and gel concentration on the retained permeability.

Figure 17 represents the permeability of 20/40 HSP proppant as function of extended time, all plots show that more the time is extended more that the permeability impairment is severe.

As plotted in (Fig. 17) when using no gel concentration, the permeability impairment was low, and the decrease of proppant permeability was due to the pressure applied for long time. When using $50 \mathrm{lb} / 1000$ gal of crosslinked guar gel, the permeability was around $170 \mathrm{mD}$ after $12 \mathrm{~h}$. A drop of $25 \%$ was reported after $24 \mathrm{~h}$, this permeability drop will continue to reach $75 \%$ after $72 \mathrm{~h}$ due to gel damage.

Figure 17 also presents the proppant permeability drop measured at $100 \mathrm{lb} / 1000$ gal of crosslinked guar gel. As presented the permeability was around $100 \mathrm{mD}$ after $12 \mathrm{~h}$, a decrease of $20 \%$ in the retained permeability was observed after $24 \mathrm{~h}$, as the time extends the damage increases and the permeability recorded after $72 \mathrm{~h}$ was more than 3 times less than the value recorded after $12 \mathrm{~h}$.

Figure 17 shows permeability impairment in the same conditions using $200 \mathrm{lb} / 1000$ gal of crosslinked gel concentration, the proppant pack was totally plugged after $72 \mathrm{~h}$, even though we reported a permeability of $1 \mathrm{mD}$ after $12 \mathrm{~h}$ which indicates the severity of the damage associated with gel concentration under bottom-hole conditions. The gel residues were very hard to be removed from the proppant pack, and the permeability was totally damaged.

The results reported from this study proved that the amount of retained permeability that can be achieved is directly related to the time of the fracturing fluid existence inside the proppant pack. This phenomenon can be explained by the gel retention related to time on adsorption of fracturing fluid and the energy required to move the gel molecules (Fig. 18). This was confirmed by (Saurabh Mishra 2014) showing that as time increases more adsorption sites of sand 
Fig. 17 Effect of Guar gel at extended time under $6000 \mathrm{psi}$ stress on 20/40 mesh size HSP proppant permeability

\section{0/40 HSP Permeability VS Gel Concentration \& Extended Time $6000 \mathrm{psi}$}

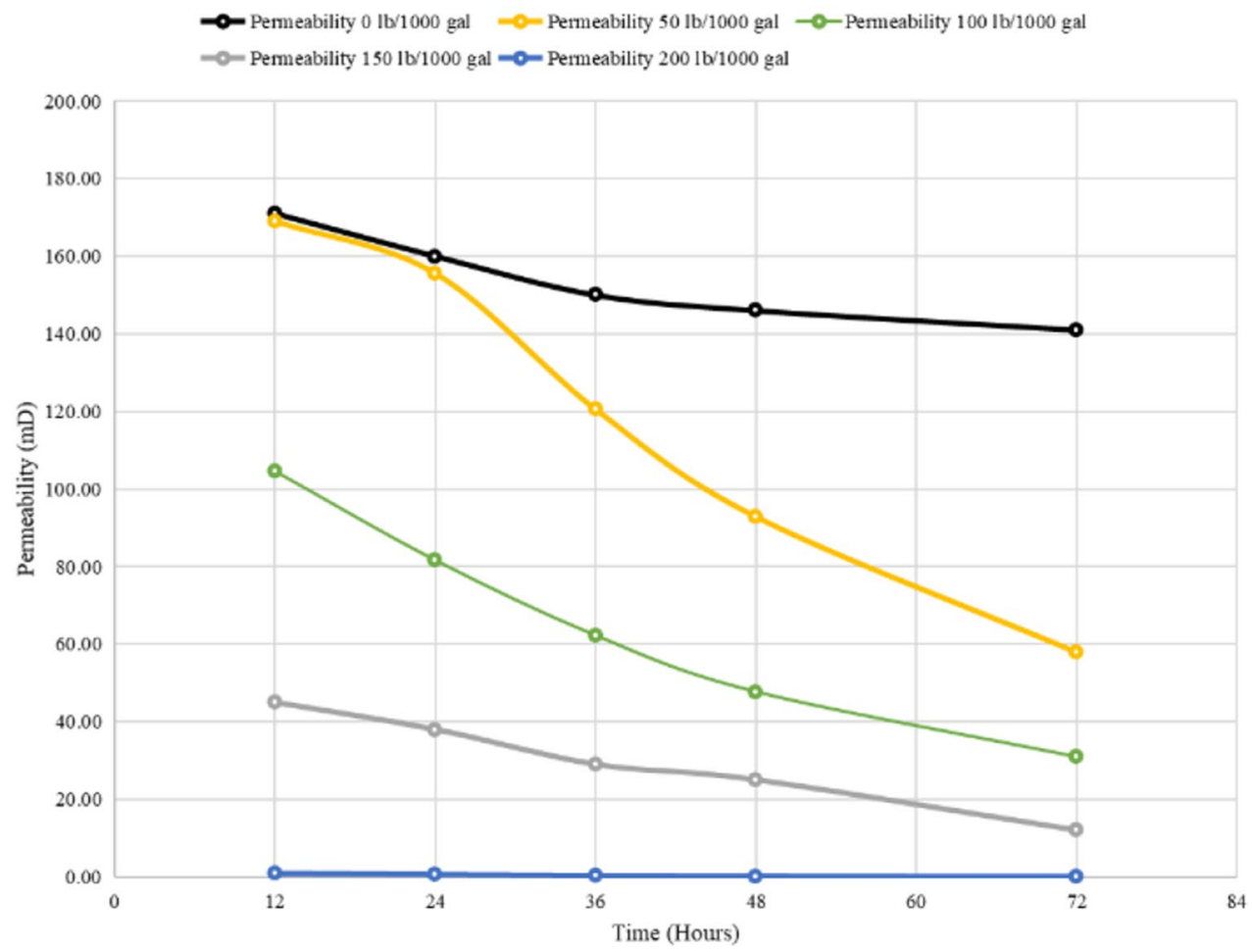

are covered with polysaccharide polymer which causes permeability reduction.

The pseudo-second-order kinetic model describes the dependency of the adsorption capacity of the adsorbent on time and can be determined based on Eq. (2) expressed as:

$t / q_{t}=1 / K_{2} q_{e}^{2}+t / q_{e}$

where $q_{t}$ and $q_{e}$ are the amounts of gel adsorbed at equilibrium and at time $t$ (minute), respectively, and $K_{2}$ is the pseudo-second-order rate constant $(\mathrm{g} / \mathrm{mg} / \mathrm{min})$. The linear plot of $t / q_{t}$ against time is used to determine $q_{e}$ and $K_{2}$ from the slope and intercept, respectively. This phenomenon which is directly related to the contact time was also the subject of (Shijie Zhu 2021) where the relationship between the adsorption amount and time was established by studying the capacity of quartz sand to adsorb polymer from solution at different periods of contact, the main result was that: as the polymer solution and quartz sand contact period increases, the polymer solution adsorption capacity gradually increases and tends to stabilize after a specific time. The adsorption phenomenon is due to intermolecular electrical effort of Van Der Valls between gel and grain surface.

\section{Effect of fracturing fluid concentration on proppant permeability}

Figure 19 represents the permeability of 20/40 HSP proppant as a function of gel concentrations $(0,50,100,150$, $200 \mathrm{lb} / 1000 \mathrm{gal})$ at extended time $(12,24,36,48,72 \mathrm{~h})$, the figure illustrates how permeability is affected when the after-closure gel concentration is increased.
Fig. 18 Effect of guar gel at extended time size on proppant permeability

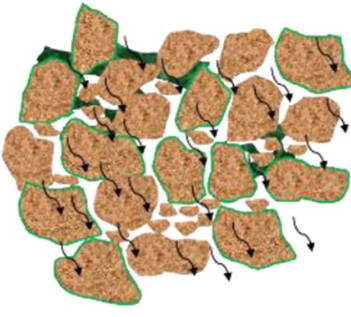

After 12 hours- High permeability Before cleanup
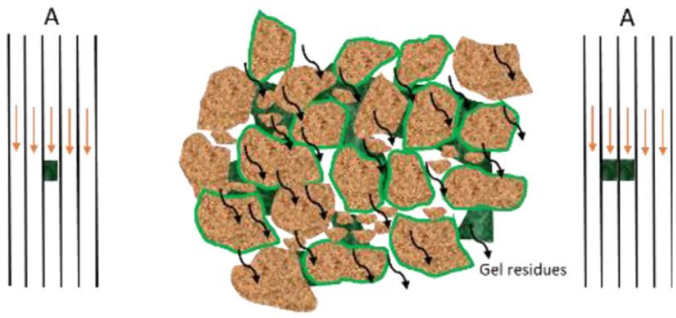

After 48- Low permeability Before Cleanup

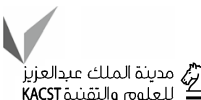


As an example, $16 \%$ drop of permeability was observed when using $50 \mathrm{lb} / 1000$ gal after $36 \mathrm{~h}$ compared to proppant permeability with no gel, while 3 times drop of permeability was measured using $100 \mathrm{lb} / 1000 \mathrm{gal}$ of fracturing fluid. Finally, the retained permeability was approximatively $0 \mathrm{mD}$ using $200 \mathrm{lb} / 1000 \mathrm{gal}$ of gel.

Another example which shows that the severity of damage increases as the polymer concentration increases using 20/40 HSP Proppant type, a $36 \%$ of retained permeability was observed after $72 \mathrm{~h}$ when using $50 \mathrm{lbs} / 1000$ gal, and $20 \%$ of retained permeability when using $100 \mathrm{lbs} / 1000$ gal. The proppant pack was completely plugged when using $200 \mathrm{lb} / 1000$ gal as gel concentration.

These results reveal that more the fracturing fluid stays in the proppant pores more that it is stuck and difficult to be removed (Fig. 20). This can be explained by Freundlich adsorption model, it is an empirical formula for heterogeneous adsorption given by the following equation:where $K_{F}\left(\mathrm{mg}^{1-(1 / \mathrm{n})} \mathrm{L}^{1 / \mathrm{n}} \mathrm{g}^{-1}\right)$ is a constant correlated to the relative adsorption capacity of the adsorbent, and
$q_{e}=K_{F} C_{e}^{\frac{1}{n}}$

$n$ is a constant indicative of the intensity of the adsorption. As the Freundlich model is an exponential equation, it assumes that the adsorption capacity of the adsorbent increases with increasing concentration of the adsorbate. The values $K_{F}$ and $1 / n$ can be correlated to the adsorption capacity and intensity (Freundlich 1926).

(Saurabh Mishra 2014) proved that when polymer concentration increases the thickness of the adsorbed layer increases and the permeability reduces. This is because the probability of interaction between sand surface and polymer molecules increases.

\section{Effect of breaker concentration on proppant permeability}

Figure 21 represents the permeability of 20/40 HSP proppant as a function of breaker concentrations $(0,5,10$, $20,25 \mathrm{lb} / 1000 \mathrm{gal}$ ) after $24 \mathrm{~h}$, under closure pressure of $6000 \mathrm{psi}$ and $120{ }^{\circ} \mathrm{C}$ with gel concentration of 50, 100 and
Fig. 19 Comparison of Effect of guar gel concentrations on 20/40 mesh size HSP proppant permeability at extended time under 6000 psi

Gel Concentration VS Permeability

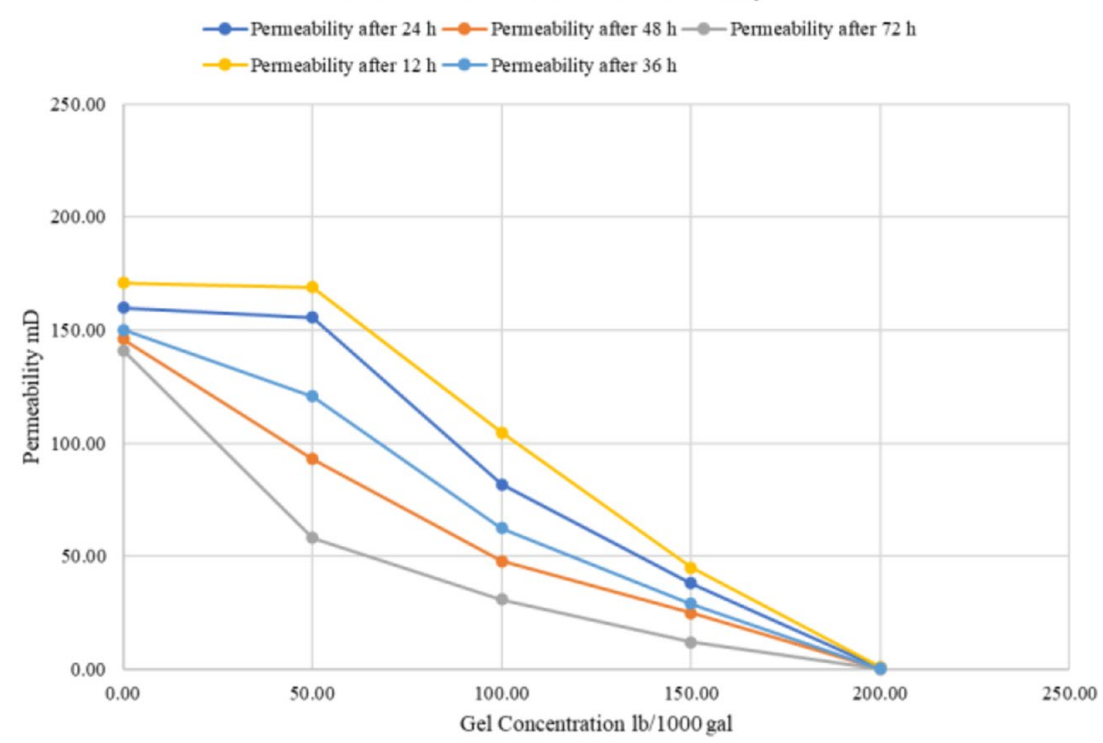

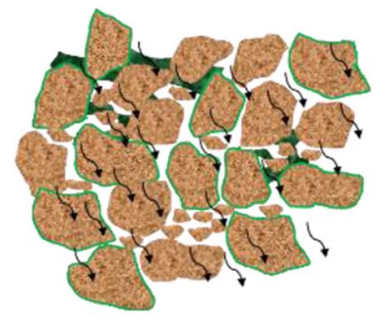

$50 \mathrm{lb} / 1000 \mathrm{gal}$ gel concentration- High permeability Before cleanup

A

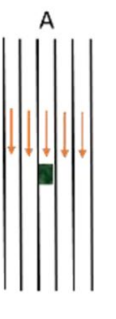

concentration on proppant permeability

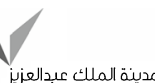

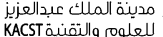
Springer

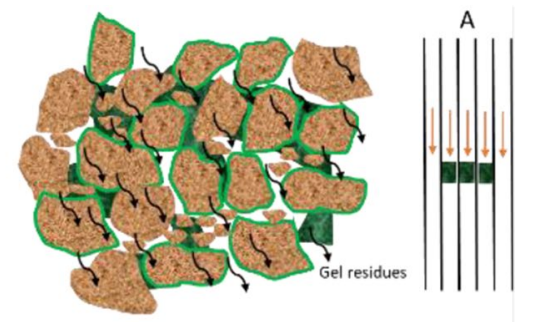

$150 \mathrm{lb} / 1000$ gal gel concentration- Low permeability Before Cleanup 
$150 \mathrm{lb} / 1000$ gals, the figure illustrates how the permeability is affected when the breaker concentration is increased.

The results show that when increasing the breaker concentration, the severity of proppantpack damage caused by concentrated polymers will reduce. The amount of retained permeability that can be achieved is directly related to the breaker concentration \&.

As presented in the chart, the retained permeability of proppant is zero when there was no breaker used and the damage was severe, the permeability then increases with breaker concentration increasing. It is important to note that for high gel concentrations more breaker is required to gain more proppant conductivity. The curves tend to stabilize at concentrations greater than $20 \mathrm{lb} / 1000$ gal where the gel is totally broken.

By cutting the long chain of polymer, the breakers reduce the viscosity of the fracturing fluid thus reducing its molecular weight which is considered to be in the range of 2 to 4 million. To eliminate the viscosity of a single guar polymer, it must be cut into approximately 200 small pieces (Acton 2013). Borate crosslinked polymers are known to be reversible thus they are broken by breaking down their molecular weights. However, the degradation of gels does not mean the fluid return because after degradation there are lots of residues left to damage the permeability of cores as illustrated in Fig. 22.

The mechanism of gel degradation is explained by the process by which the oxidant works. They release free radicals that act on the oxidizable bonds which are susceptible. Free radicals are charged ions with unpaired electrons and are highly reactive because of the natural tendency to form electron pair bonds and can generate free radicals by stabilizing the thermal or catalytic activation of oxidizing species (TjonJoePin 1996).

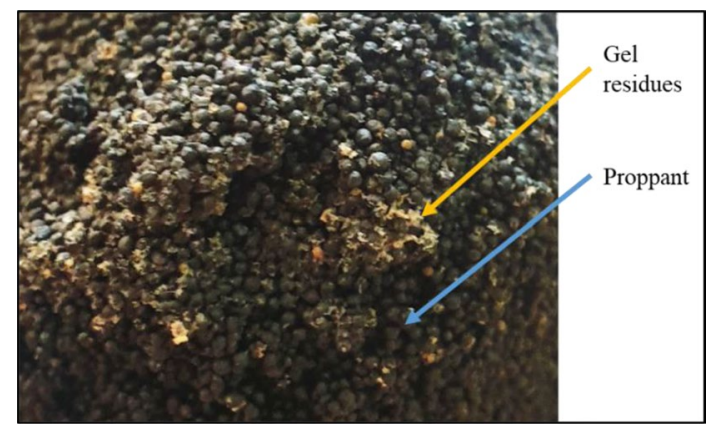

Fig. 22 Gel residues after $24 \mathrm{~h}$ under $6000 \mathrm{psi}$ at $120{ }^{\circ} \mathrm{C}$ with $5 \mathrm{lb} / 1000$ gal breaker concentration

\section{Effect of polymer concentration at extended time on Fcd and FOI}

In 1961, Prats discussed the importance of the dimensionless fracture conductivity Fcd:

$\mathrm{Fcd}=\frac{K_{f} W}{K X_{f}}$

$K_{f}$ is the fracture permeability (md), $W_{f}$ is the fracture width ( $\mathrm{ft}$ ), $K$ is the formation permeability (md), $X_{f}$ is the fracture half-length (ft).

This parameter represents the ability of fractures to transmit fluids from reservoir to the wellbore divided by the ability of the formation to transmit fluids to the fractures (Economides 2000). A coefficient $\mathrm{C}$ can be multiplied to the Fcd equation to include the effect of pressure applied on proppant, fracturing fluid and damage associated with time before cleanup.
Fig. 21 Effect of breaker concentration on proppant permeability after $24 \mathrm{~h}$, under 6000 psi and $120^{\circ} \mathrm{C}$, using $20 / 40$ HSP proppant size and different gel concentration

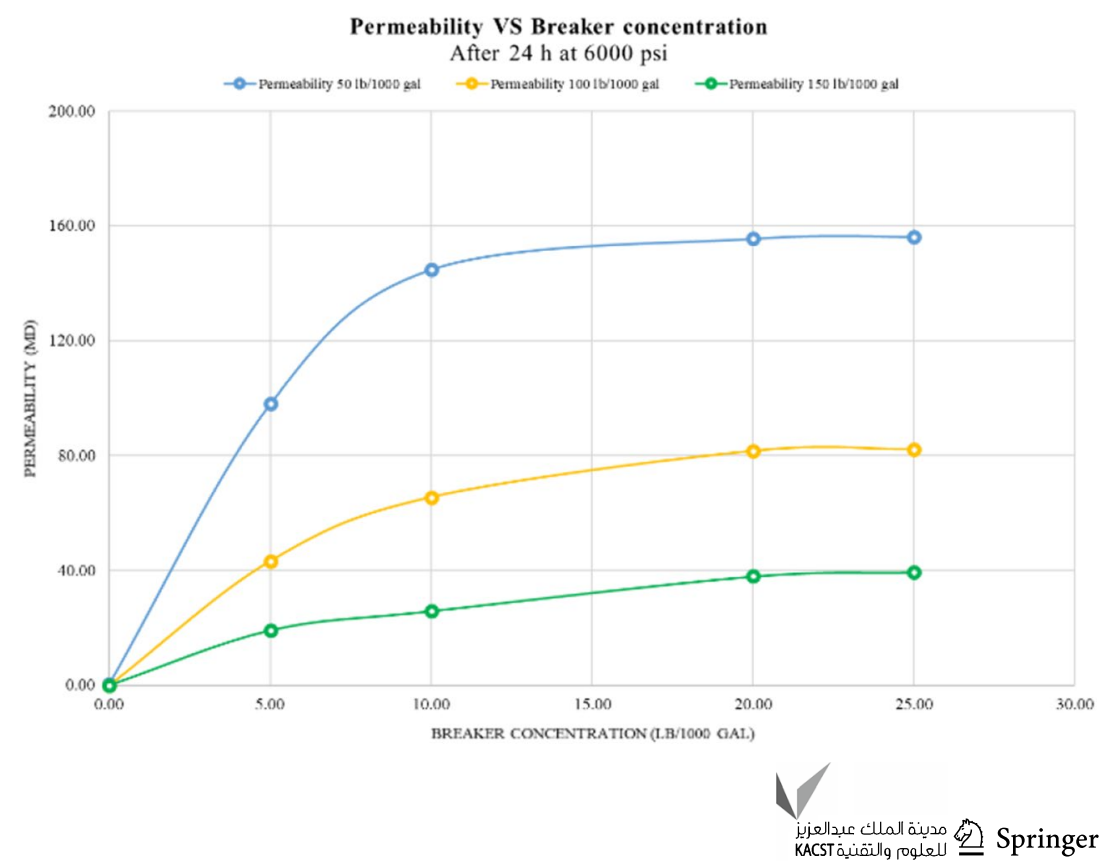


Going back to Table 1, the post-fracturing production rates are directly related to the permeability of the fractures, Prats introduced a critical concept of effective wellbore radius $r_{w}^{\prime}$ which shows how the wellbore radius can theoretically be increased after fracturing treatment. Cinco-Ley et al. (1978) later integrated this into a full description of reservoir response where they expressed $r_{w}^{\prime}$ as function of length and Fcd (Economides 2000).

Figure 23 can be used as a reservoir engineering tool to assess possible post-fracture productivity benefits from fracturing treatments. The folds of increase (FOI) can be defined as the post-fracture increase in well productivity compared with pre-fracture productivity:

$\mathrm{FOI}=\frac{\ln \left(r_{e} / r_{w}\right)+s}{\ln \left(r_{e} / r_{w}^{\prime}\right)}$

$r_{e}$ is the reservoir radius, $r_{w}$ is the normal wellbore radius, $s$ is pre-fracture skin effect.

Finally, this can significantly explain the low post-fracturing production rate recorded in some fracturing treatments performed in Hassi Messaoud field.

\section{Conclusion}

The conductivity of proppants in fractures is one of the essential parameters that condition the success of hydraulic fracturing. This parameter has already been the subject of several studies which have led to the demonstration of the importance of design on the performance of stimulation operations.

In fact, the experimental studies carried out within this research project have shown the influence of properties of the fracturing fluid and the types of proppants as well as the closure pressure and the temperature at extended time, on the proppant permeability.

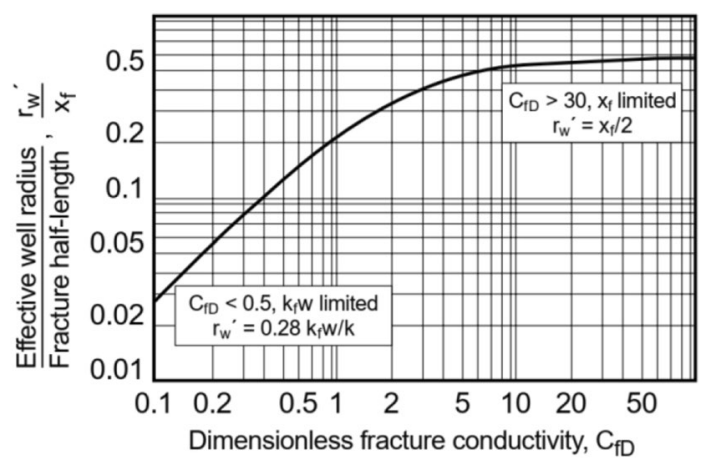

Fig. 23 Equivalent wellbore radius as a function of dimensionless fracture conductivity and fracture length (Economides 2000)
The installation developed made it possible to measure the permeability of proppants by simulating the bottomhole conditions of pressure and temperature. An increase in pressure from 2000 to 8000 psi in the confinement cell led to 66 to $89 \%$ reduction in permeability caused by the crushing of the Proppant grains under the effect of compaction. Depending on the types of Proppant 20/40 and $30 / 50 \mathrm{HSP}$, a $30 \%$ difference in permeability was obtained.

Ultra-High strength proppant type is highly recommended in Hassi Messaoud fracturing treatments.

Also, an increase in the gel concentration from 0 to $200 \mathrm{lb} / 1000$ gal showed a huge drop in proppant permeability along with concentration increasing.

Using less guar concentration is a key parameter to avoid additional damage to the fracture permeability.

The extended time between closure and cleanup is very important because more the time is extended more the proppant permeability impairment is severe.

Reducing the time between stimulation and cleanup operations in Hassi Messaoud filed is a key parameter to minimize the proppant pack permeability impairment.

Because of the rapidity of taking the measurements and the ease of handling, the newly designed installation has proven its effectiveness and has made it possible to display measurement reliability as well as data robustness.

Performing Proppant type selection through preliminary performance testing using the HPHT Containment Simulation confinement cell is highly recommended.

Choosing the type of proppants according to the closing pressure is a must which condition the success of the fracturing treatment.

Increasing the breaker concentration will reduce the severity of proppantpack damage caused by concentrated polymers.

Supplementary Information The online version contains supplementary material available at https://doi.org/10.1007/s13202-021-01364-2.

Acknowledgements Funding was provided by faculty of hydrocarbons, renewable energies, and earth and universe sciences, Kasdi Merbah university of Ouargla, 30,000 Ouargla, Algeria.

Funding Faculty of Hydrocarbons, Renewable Energies, and Earth and Universe Sciences, Kasdi Merbah University of Ouargla, 30000 Ouargla, Algeria.

\section{Declarations}

Conflict of interest On behalf of all authors, the corresponding author states that there is no conflict of interest.

Open Access This article is licensed under a Creative Commons Attribution 4.0 International License, which permits use, sharing, adaptation, distribution and reproduction in any medium or format, as long as you give appropriate credit to the original author(s) and the source, provide a link to the Creative Commons licence, and indicate if changes 
were made. The images or other third party material in this article are included in the article's Creative Commons licence, unless indicated otherwise in a credit line to the material. If material is not included in the article's Creative Commons licence and your intended use is not permitted by statutory regulation or exceeds the permitted use, you will need to obtain permission directly from the copyright holder. To view a copy of this licence, visit http://creativecommons.org/licenses/by/4.0/.

\section{References}

Abhinav Mittal CRACS (2018) Experimental proppant conductivity observations: evaluating impact of proppant size and fluid chemistry on long-term production in Shale. SPE-191741-MS, presented at 2018 SPE annual technical conference and exhibition, 24-26 September

Acton QA (2013) Reactive oxygen species-advances in research and application, 2013th edn. Scholarly edition, Atlanta

Almond SBWARH (1984) The effect of break mechanisms on gelling agent residue and flow impairment in 20/40 mesh sand. CIM 84-35-30, presented at the 35th annual technical meeting of petroleum society of CIM and Canadian association of drilling engineers, 10-13 June

API RP 61 (1989) Recommended practiced for evaluating short term proppant pack conductivity, 1st ed. s.n., Washington, DC

Barati RJSMSGDWGLJ-T (2011) Fracturing fluid cleanup by controlled release of enzymes from polyelectrolyte complex nanoparticles. J Appl Polym Sei 1292-1298

Bielewicz VKL (1998) Laboratory data on the effectivity of chemical breakers in mud. Erdöl Erdgas Kohle ed. s.l.:s.n.

Brannon HAPR (1992) Breaker Concentrations required to improve the permeability of proppant packs damaged by concentrated linear and borate-crosslinked fracturing fluids. SPE 21583, SPE Production Engineering, November, pp 338-342

Card RNKMLMSNE (1999) On-the fly control of delayed boratecrosslinking of fracturing fluids. US, Sugar Land, TX, Patent No. 5877127

Cinco-Ley H, Samaniego-V F, Dominguez N (1978) Transient pressure behavior for a well with a finite conductivity vertical fracture. SPE 6014, pp 253-264

Cooke CE (1975) Effect of fracturing fluids on conductivity. SPE, pp 1273-1282

Deuel HANH (1949) Uber die Reacktion von Borsaure und Borax mit Polysacchariden und Anderen Hochmolekularen PolyoxyVerbindungen. Makromol. Chem, p 13

Economides MJ (2000) Reservoir stimulation, 3rd ed. Third ed. s.1.:s.n. Freundlich H (1926) Colloid and capillary chemistry. Chem Educ

Gall BARC (1985) Molecular size studies of degraded fracturing fluid polymers. SPE 13566, presented at the SPE oilfield and geothermal chemistry symposium, 9-11 April

Hawkins G (1988) Laboratory study of proppant-pack permeability reduction caused by fracturing fluids concentrated during closure. SPE 18261, presented at the SPE annual technical conference and exhibition 2-5 October

International Standard, I. 1.-5., 2006. Petroleum and Natural Gas Industries. In: First ed. s.1.:s.n.

Kaufman PB, Anderson RW, Parker MA, Brannon HD, Neves AR, Abney KL, Joyce SA, Ziegler MJ, de Paiva Cortes GWK, Penny GS (2007) Introducing new API/ISO procedures for proppant testing. SPE 110697, presented at 2007 SPE annual technical conference and exhibition, 11-14 November
Kim CMALJA (1985) Fracture conductivity damage due to crosslinked gel residue and closure stress on propped 20/40 mesh sand. SPE 14436 , presented at the 1985 SPE annual technical conference and exhibition, 22-25 September

Krumbein WAMG (1943) Permeability as a function of size parameters of unconsolidated sand. SPE-943153-G, pp 153-163

Lutynski MA (2014) A method of proppant pack permability assessment. Physicochemical problems of mineral processing, 21 August

Mathew Samuel DPDG et al (2000) Viscoelastic surfactant fracturing fluids: applications in low permeability reservoirs. SPE 2000, presented at SPE rocky mountain regional/low permeability reservoirs symposium and exhibition, 12-15 March

McDaniel BW (1988) Use of wet gas flow for long-term fracture conductivity measurements in the presence of gel filter cake. SPE 17543, presented at the 1988 rocky mountain regional meeting, 11-13 May

Menjivar J (1984) On the use of gelation theory to characterize metal crosslinked polymer gels. Proc., ACS division of polymer materials: science and engineering, American Chemical Society, pp $88-95$

Misak M (1975) Temperature-stable aqueous gels. USA, Patent No. $3,922,173$

Palisch TDRBLHJAG (2007) Determining realistic fracture conductivity and understanding its impact on well performance-theory and field examples. SPE 106301 presented at the 2007 SPE hydraulic fracturing technology conference, 29-31 January

Penny G (1987) An evaluation of the effects of environmental conditions and fracturing fluids upon the long-term conductivity of proppant. SPE 16900, presented at the SPE annual technical conference and exhibition, 27-30 September

Pope DLL-WGJACV (1994) Effects of viscous fingering on fracture conductivity. SPE 28511, presented at the SPE annual technical conference and exhibition, 25-28 September

Roodhart LKTADD (1986) Proppant-pack and formation impairment during gaswell hydraulic fracturing. SPE 15629, presented at the 1986 SPE annual technical conference and exhibition, 5-8 October

Samuelson ML, Constein VG (1996) Effect of high temperature on polymer degradation and cleanup. SPE 36495, presented at 1996 SPE annual technical conference and exhibition, 5-9 October

Saurabh Mishra ABAAM (2014) Effect of polymer adsorption on permeability. J Petrol Eng 5 March

Shijie Zhu ZYZLZCJLAZX (2021) Adsorption characteristics of polymer solutions on media surfaces and their main influencing factors. MDPI, 28 May

Soto Maldonado RJ, Aoun AE (2019) A data-driven evaluation of hydraulic fracturing performance in Hassi Messaoud field, Algeria. SPE-195294-MS, presented in SPE Western regional meeting, 23-26 April

Sterling Richard SSRSABEMT (2019) Improved methods of measuring proppant conductivity. SPE-195368-MS, presented at the SPE Western regional meeting, 23-26 April

TjonJoePin RM (1996) Characterization of breaker efficiency based upon size distribution of polymeric fragments resulting from degradation of crosslinked fracturing fluids. SPE 36496

Tulissi MLSVJBDDD (2012) Fracturing method and apparatus utilizing gelled isolation fluid. US, Calgary, CA, Patent No. 8141638

Whistler R (1959) Industrial gums. Academic Press, New York 